\title{
The Digital Political Communication of South Korean Politicians
}

\section{Heike Hermanns}

\author{
Associate Professor \\ Dept. of Political Science, Gyeongsang National University, J inj u Daero 501, J inju 52820, South Korea \\ hermanns@gnu.ac.kr
}

\begin{abstract}
The internet and social media have been credited with the potential to reinvigorate democracy by offering new avenues of political participation and communication between citizens and politicians. The results of empirical studies, however, call for caution, as many politicians refrain from fully exploring the interactive potential of new media. This case study focuses on the web presence of Korean parliamentarians, using basic statistical analyses to explore the use of ICT as a means of political communication. It finds that Korean parliamentarians are less active online, treating ICT mainly as another channel for information distribution. It is thus concluded that ICT is not revolutionizing politics but reinforcing existing patterns of communication that leave a gap between citizens and representatives. This paper was previously submitted to CeDem Asia 2016. The literature review and the methodology section have been expanded, and additional statistical data as well as further findings on Twitter were added.
\end{abstract}

Keywords: politicians' digital presence, political communication, direct democracy, South Korea, National Assembly

Acknowledgement: This article is an expanded version of the paper "The Promises of Digital Political Communication and the Reality in South Korea" presented at CEDEM Asia 2016, December 7, 2016.

\section{Introduction}

The theoretical debate on democracy and its components intensified in the final decades of the 20th century, driven by two seemingly contradictory developments, the rise in the number of democracies but a decline in the (perceived) quality of democracy. While a growing number of countries turned to democracy, commentators also decried a 'crisis of democracy' in mature democracies. Falling voter turn-out, growing apathy and declining party identification as well as the rise of populist parties and movements were identified as indicators for this crisis (e.g. Putnam, 2000, Dalton \& Wattenberg, 2000, Bennett, 2008). The growing importance of the media in the 20th century, in particular, limited options of direct interaction between citizens and politicians and citi- 
zens' participation in the decision-making processes. Critics note that political participation is often reduced to voting in elections, thus removing citizens from policy-making processes (Crouch, 2004). As politics professionalizes, the direct connection to citizens weakens, leading to dissatisfaction with political processes and the growth of non-traditional political activities, such as social movements and boycotts (Norris, 2011). Young people, in particular, often feel disconnected from conventional politics (Bennett, 2008). The notion of a democratic decline has been challenged because the underlying normative assumptions concerning democracy, representation and participation are based on the mid-20th century experience, such as high levels of party membership and party hierarchies (Blühdorn, 2013). Instead, critics suggest that changing political activities and altered expectations from political institutions need to be taken into account while expectations of form and function of political participation are to be adjusted (e.g. Chadwick, 2011, Gibson \& Cantijoch, 2013). This invokes the need to change behavior and expectations by both political actors and theorists.

As new information and communication technologies (ICT) and social networking services (SNS, or social media) emerged around the same time as the (perceived) democratic decline caught attention, the connection between such technologies and the quality of democracy was added to the debate. Blogs and SNS have been suggested as a solution to the participation problem as they offer new avenues of communication between politicians and citizens. Such direct deliberation could reinvigorate democracy by cutting out the middle man and reducing the distance between politicians and citizens (e.g. Coleman, 1999). Similar claims have been made with regard to each new hardware and software innovation over the last 150 years, ranging from the telephone, radio, and television, to discussion boards, blogs, and SNS. However, the analyses of such changes are often inconclusive in the direct effect of new technologies (e.g. Macnamara \& Kenning, 2014, Norris, 2011). Political scientists tend to focus their analyses on either established actors such as political parties or citizen activities, but the connection between the two is explored less frequently (see also Wright, 2012). In light of this lacuna, this paper explores if and how ICT enhanced, changed or maintained established patterns of political participation and representation, focusing on the Republic of Korea (hereafter South Korea or Korea) as a case study. The broader goal is to explore the connection between the theoretical considerations on ICT with the debate on digital democracy, using Korea as a case study. More specifically, the paper looks at the different social media used, the content of posts, and the frequency of use for interaction. The results show the limitations of the techno-determinist view that ICT will induce an era of direct democracy. Korean politicians use ICT for information provision but rarely to encourage participation. At the same time, citizens are also less likely to engage on such platforms with politicians. Instead, Korean citizens use ICT as a parallel space of political discussion where they frame debates and demands, aiming at the political elite.

Following the frame of other studies on politicians' use of ICT in established democracies, this paper looks at the social media presence of Korean parliamentarians and how they use such media to connect with citizens (e.g. Gibson \& McAllister, 2006; Gibson et al., 2008; Larsson \& Moe, 2011; Hansen \& Kosiara-Pedersen, 2014, Sørensen 2016, Ross et al., 2015). South Korea is a young democracy with high internet use, so the paper aims to provide some insights for other researchers looking for comparative material on online activities by politicians, using similar variable of analy- 
sis. Building on Stein's typology $(2009,752-3)$, online communication is taken to include a number of variables, namely, the provision of information, the promotion of interaction and dialog, and efforts of fundraising and resource generation. Using these factors, this study analyzes whether and how Korean politicians actively use ICT and social media as a (genuine) means of communication to engage with citizens. This leads to the two research questions.

RQ1: Which features do Korean parliamentarians include on their websites and social media presence and how prevalent are these features?

RQ2: To what extend do Korean parliamentarians use the web to engage in primary communication functions?

In answer to the first question, this paper explores the online presence of National Assembly members and whether they use ICT as an authentic means to communicate or simply as an information channel. The second question prompts a look at the parliamentarians' communication with citizens across a number of popular platforms. Korean parliamentarians and their online presence has been subject to several studies, but the focus tends to be on quantitative analyses, such as online presence (Park et al., 2004, Park \& Kluver, 2007, Park et al., 2011), web and Twitter networks (Hsu \& Park, 2011, Kim \& Park, 2012), features used on Twitter (Lee et al., 2011), and the connection between online presence and finance (Lim \& Park, 2013). This paper adds the dimension of web presence and its connection to communication and engagement with citizens across a number of media platforms to capture a fuller picture of online activities. As a caveat applicable to all studies on ICT, it should be noted that the paper refers to social media used in late 2015 and 2016. Given the quick rise and decline of social media applications, the findings are ephemeral and may date quite quickly.

The remainder of the paper proceeds with an overview of the literature on the topic, followed by comments on the development of ICT in South Korea and recent events where digital media have affected mobilization and political outcomes. The third section introduces the methodology briefly. The fourth part focuses on the analysis of the social media presence of members of the National Assembly in late-2015 and early 2016, an explorative study rather than in-depth quantitative analysis, as findings were often not statistically relevant due to the low count of online activities. In light of their differences, each social media platform is explored separately. This is followed by a discussion of the findings, the challenges to democratic representation, and methodological considerations raised by this case study. The paper expands the conference presentation delivered at CeDem 2016 in Daegu, South Korea, in December 2016. The paper has been restructured, and the sections on the methodology and Twitter use, in particular, have been expanded. Furthermore, additional detailed statistical data has been included in the text and in tables. 


\section{Review of the Literature}

\subsection{Effects of ICT on Politics}

Since the 1990s, the opportunities and effects of ICT on politics have been subject to many studies, both theoretical and empirical (e.g. Chadwick \& Howard, 2009). The focus of attention shifted from e-government and e-voting to the provision of information, deliberative spaces and ICT's mobilization potential. On the normative level, the importance of citizens' conversation about politics has long been recognized as an important component of a healthy democracy (e.g. Habermas, 1990, Norris, 2011). Public deliberation is described as a cornerstone of participatory democracy which could overcome some of the noted problems of policy-making and representation in established democracies (e.g. Blumler \& Coleman, 2011). The internet allows immediate contact not only between citizens but also between citizens and political decision-makers, and opens avenues for in-depth public deliberation with many participants, furthering democratic ideals (e.g. Morris, 1999, Coleman \& Shane, 2011). Internet forums have gained attention as spaces of deliberation, not just for debate but also for the creation of new networks and civil spirit (e.g. Coleman \& Blumler, 2009, Wright, 2012).

The literature on ICT and politics can be broadly categorized into two contrasting evaluations, the optimistic 'revolution' perspective and the more skeptic 'reinforcement' or 'normalization' perspective. The former welcomes new ICT as a force to revive and reinvigorate democracy, by offering easy access to information, and inclusive and broad citizen participation in the decisionmaking process. Moreover, new ICT are credited with opening new public spheres for discussion and deliberation (Davis, 2009, Morris, 1999, Rheingold, 1994, Shane, 2004). The spread of information is seen as revolutionizing (Trippi, 2004), with the internet emerging as the fifth estate (e.g. Morris, 1999). It is argued that agents involved in political decision-making processes can solicit citizens' input through various means, including online town meetings, discussion boards and feedback mechanisms on their websites. ${ }^{1}$ Optimists highlight the democratizing potential of ICT, allowing for fast and direct communication between politicians and citizens, even while in parliamentary session (e.g. Blumler \& Kavanagh, 1999, Coleman 2005). However, there is the cautionary note of the normalization perspective, that parliamentarians may be distracted by social media while in parliament (which has led many parliaments to debate this question; Williamson, 2013). The openness of a politician's blog or wall to outside posts and the open comment sections offers greater opportunities for engagement, but also raises concerns over the need for and extend of moderation. As social media become more widespread and regular posts are expected, many politicians may engage assistants to handle their account, creating another form of gatekeeper controlling access to the politician, which counters the revolution perspective.

The reinforcement perspective takes a more cautious tone, initially highlighting the digital divide (Norris, 2001) and the danger of fractionalization (van Alstyne \& Bryndfissoon, 1997). As the internet was incorporated into daily life across the globe, most concerns over exclusion were dis-

\footnotetext{
${ }^{1}$ See Kies (2010) for an in-depth discussion of online deliberation.
} 
persed (e.g. Chadwick \& Howard, 2009). Critics in the reinforcement camp remain skeptical of the transformative power of ICT, highlighting, for instance, the strengthening of existing patterns of participation and communication: while those already active in politics adapted to new technologies, there was no increase in the number of activists (e.g. Norris, 2000, Margolis \& Resnick, 2000, Brandenburg, 2006, Riles et al., 2017). Strandberg (2013) highlights that online presence is not the same as engagement with citizens (for further discussion, see also Hsu et al., 2013, Enli \& Skogerbø, 2013). The quality and effect of online debate remains disputed, as empirical studies indicate that many people are more likely to seek and be exposed to posts with attitudes similar to their own or be exposed to similar views in their networks (also termed "filter bubble" or "Cyberbalkans"; van Alstyne \& Bryndfissoon, 1997, Dahlberg, 2007, Riles et al., 2017). The format of short and frequent exchanges lessens the investment in time and effort on posts, widening the pool of participants (Park, 2013). Political views can be expressed simply by clicking 'like' or signing a petition electronically. However, such digital activism has been criticized as 'slactivism' or 'clicktivism', implying that these acts provide a feel-good factor but have little direct political impact (Christiansen, 2012, Halupka, 2014, Morozov, 2009).

Proponents of the reinforcement perspective also highlight that traditional media continue to play a role of trendsetters and multipliers (e.g. Farrell \& Drezner, 2008, Madianou, 2012). Reports on trending topics in social media on TV or in news reports, for instance, reach a wider audience than the actual messages, and often cross-fertilize each other (becoming 'polymedia events', e.g. Choi \& Chang, 2015). ${ }^{2}$ While ICT have reduced the role of gatekeepers in traditional media, popular bloggers, Facebook and Twitter posters now fulfil a similar function as multiplier of posts. Many politicians therefore treat the internet as an extension of established pathways and settings rather than a new tool of political communication and participation (e.g. Ward et al., 2003). The role of traditional opinion leaders is reduced by the minimal cost of participation on social media. The growing normalization of social media (apps like Facebook, Twitter, Whatsapp) as news outlets over the last few years has brought some changes in the use of social media by politicians. A prominent example is US-President Donald Trump, who prefers to communicate via Twitter rather than established political channels. On a practical level, Trump's preference raises questions about the role of social media as official governmental information channels, a challenge many other institutions also face. On the theoretical level, such developments add to the reinforcement perspective, namely that social media are becoming just another channel of information distribution.

\subsection{Empirical Studies}

A plethora of empirical studies has been published on the opportunities offered by the internet to change democracy and political activities. Initially, the focus lay on activities by political actors,

2 'Polymedia events' are events which start in the virtual world but become popular online as well as in the traditional media (Madianou, 2012). One current example for this media interdependence is the use of Twitter as an official outlet by US-President Donald Trump and the reports of such tweets across all media. 
such as intra-party communication and campaigning (e.g. Kluver et al., 2007, Gibson et al., 2008, Vergeer et al., 2011). Early visions of ICT included hopes that parliamentarians could directly connect with voters during the decision-making process (e.g. Coleman, 2005). 'Web 2.0' with its interactive features offers manifold opportunities to produce content, leading to the proliferation of participatory activities among internet users, such as blogs and discussion sites on political affairs (Valenzuela et al., 2012). Social media in particular offer a number of ways for politicians and activists to connect with citizens to identify emerging issues and trends. During election periods, politicians increase their social media presence, but their activities tend to decline outside election campaigns, indicating that social media are used merely as another means of information provision (e.g. Vergeer et al., 2011). Gibson (2015) notes how the spread of SNS facilitates the outsourcing of conventional campaign activities in US-elections, like coordinated phone calls. In the research on politicians' digital presence, there has been a focus on output, the existence and availability of websites among politicians, their service features, and hyperlinks (Kluver et al., 2007, Lilleker et al., 2010). Since Twitter entered the public consciousness as a new tool of political communication in 2007, researchers noted a reinforcement trend in many countries: the same group of (already engaged) users communicated with each other on this new medium (e. g. Larsson \& Moe, 2011; Vergeer et al., 2013). The uptake of online communication, i.e. the vertical connection with citizens, gained some scholarly attention (e.g. Gibson \& McAllister, 2006). Previous research on politicians' activities on social media concludes that the influence on public opinion is limited (e.g. Larsson \& Moe, 2011, Macnamara \& Kenning, 2013, Ross et al., 2015). The link between the use of Twitter for political purposes and political engagement in real life remains tentative (e.g. Park, 2013). Looking at American politicians on Twitter, Hong and Nadler (2011) and Nielsen (2011) find that their tweets had little impact on public opinion. More recent research in European countries indicates a change; Frame and Brachotte's study (2015), for instance, shows that some French politicians are actively engaging on Twitter. Sørensen's work (2016) on representatives in Denmark finds that the comment sections on politicians' Facebook pages have developed into discussion spaces. However, only a handful of politicians participated in a discussion on their site. In many other cases, the discussion developed among commentators (ibid., 671, 674), highlighting again the gap between politicians and citizens.

Other empirical studies on social media and political participation offer similar inconclusive findings, but continue to highlight the potential for digital mobilization and engagement (for more discussion, see Koc-Michalska et al., 2016, Skoric et al., 2016). Horizontal communication on open platforms played a vital role in recent political events across the globe, such as the antiglobalization movement (Bennett, 2003, Pickerill, 2004), the Arab Spring (Chebib \& Sohail, 2011), and the Occupy Movement (Jensen \& Bang, 2013). One common theme in these movements is the focus on specific goals, demanding direct action by the executive. Such movements are less likely to engage with representatives of political institutions, especially in a prolonged and organized manner. While this activism can be described as a form of direct democracy, it does not offer a means for day-to-day administration or provide for key elements of democracy such as minority protection. In light of these diverse findings, the debate on the long-term effects of new media on political participation and citizen representation thus continues (e.g. Blühdorn, 2013). The emergence of different models of democracy, like direct or deliberative democracy, is by no means guaranteed. Representative democracy remains the norm in most democracies, so politicians' will- 
ingness to engage through ICT is crucial but not inevitable (e.g. Enli \& Skogerbø, 2013, Lilleker et al., 2011). The analysis of the effects of ICT and social media with their dialogic character on vertical communication and the opening of new participatory avenues in representative democracy thus warrants further study.

A common thread in such empirical studies are the challenges of social media as a tool for political communication. However, a number of caveats should be noted. Social media offer different levels of publicity. Facebook allows restrictions in order to limit access to a network (i.e. friends and followers). Twitter, in contrast, is open to the public and users can share and respond, thus opening a new, broad, non-hierarchical forum for public discourse (Kim, 2011). The number of followers is often seen as an indicator of popularity (e.g. Lee et al., 2012). Using such data to this end is problematic, because it underestimates the variation in motivations to follow an account. Such numbers may serve as an indicator of the audience size but not all the accounts following may be active or feeling positive about the account holder (Strandberg, 2013). In addition, recipients may not read all posts, since it is often considered good etiquette to follow someone who follows one's own account (Cha et al., 2010). For politicians, following a large number of accounts also carries risks: one may become overwhelmed by posts and thus less likely to engage.

\subsection{Internet Usage in South Korea}

This paper uses South Korea as a case study, a relatively young democracy (since 1988) with internet-savvy citizens. Democratic political institutions are well-established although there remain some short-comings, such as a weak party system and the personalized style of politics (e.g. Kim, 2014). South Korea is an early adapter to new ICT infrastructure as well as usage of digital media in all spheres of life, including politics. ICT and social media have increased citizens' mobilization and organization on a horizontal level, but established political actors are adapting to new ICT at a much slower pace (Kim \& Kim, 2009). This is been described as a divide between 'digital citizens' and 'analog politicians' (Min, 2008). The growth of social media has opened new means of vertical communication to overcome this gap. Since Korean citizens have been using digital media to organize political activities and large scale demonstrations for more than twenty years, this research started with the assumption that Korean politicians would strive to engage citizens through ICT and social media.

South Korea has a reputation as the 'most wired country' in the world, due to the early and widespread adaption of ICT (e.g. Lankov, 2011). In the late 1990s, the government launched the development of the necessary infrastructure for fast broadband and wireless connections that have become (almost) ubiquitous, at home and in public places. South Koreans are avid users of their smart phones, which offer easy and constant access to social media through relatively cheap data plans. Over the last decade, there has been a shift from domestic apps to overseas ones. While social networking service cyworld and its personal homepages called 'mini-hompy' were hugely popular in the mid-2000s, the company ended its services in 2015 (Park et al., 2011). The big portal services, daum.net and naver.com, offer community sites called 'café' which are also losing in popularity to blogs, Facebook and Twitter. About two thirds of Koreans used social media in 2015, with profile-based services such as Facebook and Korean-developed kakao story being very popu- 
lar (88.4\% of SNS users [MSIFP 2016]). In 2016, kakao story reportedly had 14 million users (Lee, 2016), while around 16 million Koreans used Facebook (Internet Statistics, 2016). ${ }^{3}$ Kakao story's popularity is related to its connection with kakao talk, an instant messaging service that is used almost universally in Korea (in 2015, over $90 \%$ of Koreans had an account and $88 \%$ had accessed it within the previous week [MSIFP 2016]). Four out of ten social media users participated in online 'cafés' while over a quarter maintained a blog (MSIFP, 2016). Micro-blogging site Twitter was less popular; in 2013, it was estimated that there are around 7.5 million subscribers but only one million active accounts, mostly among the younger generation (Emarketer, 2014; newer data remains elusive despite the author's best efforts). In 2016, the general statistics on Korean Twitter users and their following under the category 'politics' featured only two politicians in the top ten, as political pundits attract more followers (Socialbackers, 2016). The list was topped by then-opposition leader Moon Jae-in (with over 900,000 followers), followed by pundits and commentators. ${ }^{4}$ In 2011, conservative members of the National Assembly were more likely to have a Twitter account, in particular newer members, but Twitter users were more likely to follow progressive politicians (Lee et al., 2012).

\subsection{Social Media and Political Mobilization in South Korea}

Over the last two decades, the role of ICT and social media in political activities and discussion has expanded substantially in Korea. In the late 1990s, dedicated discussion sites and political commentators' sites opened new spaces for debate as well as the provision of information (Chang, 2005). In the early 2000s, online newspapers, most notably Ohmynews, opened the way for new forms of journalism and platforms for debate and political engagement (e.g. Yun, 2003). Online fan clubs are credited as major contributors to the electoral success of President Roh Moo-hyun in 2002 (Chang \& Lee, 2006). Around the same time, the rapid expansion of mobile phone usage changed mobilization processes as text messages proved useful to galvanize friends and acquaintances to join protests, like the 2002 demonstrations against the presence of US-troops on Korean soil and the 2004 protests against the impeachment of President Roh Moo-hyun (ibid.). Demonstrations turned into social events, as friends used social media to encourage each other to join and to connect at such events. Mobile devices also helped to provide further direct information as comments, photos and videos could be taken and uploaded in real time for further discussion and mobilization.

From 2005 onwards, a shift from text messages to online communication on blogs and in chat rooms was notable, facilitated by the spread of smart phones and ubiquitous Wi-Fi. This aided the mobilization of numerous protests, most markedly the 2008 anti-beef demonstrations. Galvanized by a TV-program on the potential risks of consuming imported beef, online forum users not only

${ }^{3}$ By May 2017, the numbers of monthly active users had declined. 9.96 million users logged into Facebook, while 12.59 million users visited kakao story (Yoon, 2017).

4 The number of Twitter users increased over the course of 2016 and early 2017, as political unrest grew and, following the successful impeachment of President Park Geun-hye, presidential elections were held in May 2017. In mid-2017, the three most popular politicians each had over one million followers (Socialbackers, 2017). 
discussed the threat but also organized demonstrations against the beef imports in the streets of Seoul that lasted for several months. The initiative had no central organizers but originated in diverse forums, such as fan clubs for boy bands and shopping advice sites (Kim \& Kim, 2009, Min, 2008). In Korea, as in many other countries, Twitter has been credited with affecting recent election results, in particular with increasing voter turn-out (e.g. Chang, 2014, Lee at al., 2012). Although, as noted above, the number of actual Twitter users remains relatively low, tweets gain attention in other media, thus amplifying the reach. Twitter is used to spread political messages as well as a means of expanding social networks for political ends (Lee et al., 2012). In the 2016 demonstrations over the impeachment of President Park Geun-hye, social media and messaging services were important to coordinate participation and activities not only to mobilize but also whilst in attendance (author's observations).

Online political activity in Korea, similar to other countries, was generally driven by the younger generation and, at least initially, favored opposition politicians (e.g. Bakker \& de Vreese, 2011, Lee et al., 2012). While digital media were dominated by progressive forces in the early 2000s, conservatives caught up in the following years, normalizing ICT use among politicians (Hermanns, 2015). Korean political parties have been reluctant to embrace new media for communication. Nevertheless, several parties experimented with open primaries to extend the candidate selection process beyond party members. The general public was invited to register and vote by phone or text message for their preferred candidate (e.g. Park, 2014). While popular among Korean citizens, this method reduces the role of political parties as gatekeepers to political office and turns the nomination process into a popularity contest. Open primaries aside, political activities in the Korean online sphere are generally citizen-driven. Relying on online activities, citizens are seeking direct influence on government policy, rather than drawing on the indirect means of representative democracy, exposing the gap between 'analog politicians and digital citizens' (Min, 2008). The following aims to analyze if this statement is still apt nine years later, or if politicians have adapted to the high social media use among citizens and opened new avenues of communication and participation.

\subsection{National Assembly Members}

The 19th Korean National Assembly was elected on 19 April 2012 and comprised 300 representatives. 246 parliamentarians were elected directly in districts, and 54 representatives were appointed from proportional lists. At the time of data collection in February 2016, the number of parliamentarians had dropped to 294, including 53 members appointed on proportional seats. Among the representatives were 250 men and 44 women, ranging in age from 35 to 74 years. The mean age was 52.8 years $(S D=7.7)$. The data was collected after the main opposition party, the New Democracy Party, had split in early 2016 to form the Minjoo Party of Korea (105 representatives) and the People's Party (17)..$^{5}$ In addition to the then-ruling conservative Saenuridang (161 representatives), there were five representatives of the left-wing Justice Party, and six independents. More than half

\footnotetext{
${ }^{5}$ Such rearrangements are not rare in Korean politics, reflecting the prevalence of personalized politics and
} factionalism (Kim, 2014). 
of the politicians sat in the National Assembly for their first term (51\%), while $22 \%$ served a second term and $16 \%$ their third. 29 members had been elected four times or more, including one representative who had served seven terms in the National Assembly since 1981 (and was elected for his 8th term in April 2016). With one exception, all representatives had some form of web presence; Facebook and personal websites being the most popular (283 and 282 respectively; Table 1). Most parliamentarians also had a blog (161) and a Twitter account (242). In addition, an array of other social media were used, including YouTube (43 representatives), Instagram (23) and kakao story (18).

Table 1: number and percentage of Korean National Assembly members using social media in February 2016 (source: author)

\begin{tabular}{|l|l|l|c|c|c|c|}
\hline & Facebook & $\begin{array}{c}\text { Personal } \\
\text { website }\end{array}$ & Blog & Twitter & Other & None \\
\hline Number & 283 & 282 & 161 & 242 & 84 & 1 \\
\hline percentage & 96.3 & 95.9 & 56.8 & 82.3 & 28.6 & 0.3 \\
\hline
\end{tabular}

\section{Methodology}

This paper is a case study to capture the use of social media by Korean politicians in late 2015 and early 2016. Due to its origin as a conference paper, it is not intended as an in-depth quantitative study, so the statistical analysis remains superficial, not the least due to data constraints. A further in-depth content analysis of posts is in progress. The paper focuses on politicians elected to the Korean National Assembly, excluding other actors engaged in political communication, such as politicians outside parliament, civil activists, academics, and political pundits. The web presence was confirmed through two sources. The website of the National Assembly provides a directory of all representatives, which includes links to their homepage and email address, but no other social media contacts. Therefore, the online directory of search engine naver.com was consulted to acquire further details on parliamentarians' social media presence. In June 2015, a pilot was undertaken with a number of student researchers as a class project to test data collection and coding schemes; the code book was subsequently adjusted accordingly. Due to time constraints, the data collection period was limited to two one-week windows, although a longer period would be desirable to gain more data for statistical analyses. The National Assembly was not in session when the primary data collection was undertaken by the author from February 19 to 26, 2016. In order to collect comparative data to test the effect of parliamentary sessions on activity patterns, data collection was expanded. Retrospective data for the week from November 22 to November 28, 2015, when parliament was sitting, was collected at the same time.

The data collection included all major social media applications, except kakao talk, which restricts open access and thus data collection. Only a small number of representatives had a profile on kakao story, the Korean personal profile site, so it is not covered here. For each politician, a set of information was collected, including personal characteristics (age, gender, hometown, party affiliation, method of election). The data was compiled by visits to the relevant websites by the researcher, covering a number of variables, namely, the provision of information, the promotion of 
and engagement in interaction and dialog, and efforts of fundraising and resource generation. For websites, only the opening site was considered, noting main content, the number of updates during the two observation weeks, and the option to donate. With regard to blogs, it was noted if this was the primary site, the date of the last post, and the frequency of posts during the two weeks for which data was collected. For Twitter, the number of followers and accounts followed as well as the last date of an activity was noted and later recoded into groups. Moreover, the number of tweets, retweets and replies in the relevant weeks was counted. The Facebook presence was split into two options, personal profiles and pages, and recorded separately. Following the model for Twitter, the date of the last entry, and the frequency of posts and replies was recorded. Additionally, the number of likes, friend and followers was noted.

The number of activities within the set time frame was recoded on a scale, ranging from one to two posts a week ('occasional') to over 34 ('heavy'; such users are referred to as 'super users'). ${ }^{6}$ Twitter accounts were classified as 'popular' when they had more than 50,000 followers. The time of the last update was recoded, ranging from 'never' to 'within the last day', with a slight variation between blogs, Facebook and Twitter to reflect different usage patterns. The paper enumerates features and activities, but, as the results for many variables were too small to produce statistically relevant results, does not include many results of more sophisticated statistical analyses, including multiple regression analysis. During the data collection, posts were recorded and the content of posts classified, but the qualitative content analysis is not yet completed, so results are not included here.

\section{Findings}

\subsection{Personal Websites and Blogs}

All but three of the 294 National Assembly members had some form of personal website or blog. The websites of eight representatives were found to be out of service. Although 202 parliamentarians owned their own web domain, two thirds of them also maintained a blog (161). Other parliamentarians relied solely on a blogging platform as their main web presence $(82,28 \%$ of all parliamentarian). ${ }^{7}$ In the group that maintained both a website and a blog, more than half used the blog as their main site of activity. One reason for this preference could be the interface, as blogs with design templates are considered to be more user-friendly but it confuses citizens looking for the politician's website (personal communication with citizens and politician's assistant). Parliamentarians used their posts in diverse ways, including sharing information, posting reports and photos from local events they attended as well as information on their day-to-day activities. In terms of content form, information and visual contents were equally popular. Both made up around 38\% of the content, while $17 \%$ of posts consisted of links. A detailed content analysis may draw out some

\footnotetext{
${ }^{6}$ These categorizations emerged out of classroom discussions with Korean students in a class titled "Internet and Politics".

${ }^{7}$ Some percentages are rounded. This also applies to future references to percentages in the text.
} 
further insights beyond the observation that news reports on the politicians and posts on activities were frequently posted or linked. While a link for donations is a key feature in many other countries (e.g. Kluver et al., 2007), less than half of Korean parliamentarians' personal websites offered this feature $(44.9 \%)$. The set-up to collect donations was more frequently present when parliamentarians had acquired their presence personal domain, while it was more likely to be missing on blogs. This limited use of ICT to collect donations reflects political traditions, since Korean politicians tend to rely on state funding and large donors rather than individual contributions (Hellmann, 2014).

Usage frequency of websites and blogs varied substantially, ranging from 'within the last day' to 'three years prior'. Over one third of parliamentarians had not updated their website within the last month, while only $8.5 \%$ refreshed more than once a day. Only $6 \%$ of websites and $23 \%$ of blogs were updated in the week that parliament was in session, while $23 \%$ of personal websites and $17 \%$ of blogs were updated in the week without parliamentary sessions (Table 2). During the February period, the mean number of posts on websites reached $5.6(\mathrm{SD}=4.5)$, while the mean for blog posts stood at $5.99(\mathrm{SD}=4)$. In November 2015, the number was much lower, as many parliamentarians did not post at all on websites or blogs. On each medium, there was a small number of 'super updaters' who posted more than 19 updates in the previous week. These 'super-updaters' were all male representatives, but otherwise no clear correlations between update frequency and age, gender, and parliamentary experience emerged. The number of posts on personal sites and blogs is lower compared to the number of updates on Facebook and Twitter, indicating a shift towards social media among representatives.

Table 2: Update frequency on websites and blogs (source: author)

\begin{tabular}{|l|l|l|}
\hline & Website & Blog \\
\hline Total number of active sites & 202 & 243 \\
\hline Number of pages with updates in Nov. 2015 & $17(6 \%)$ & $56(23 \%)$ \\
\hline Number of pages with updates in Feb. 2016 & $47(23 \%)$ & $42(17 \%)$ \\
\hline Update mean in one week, Nov. 2015 (SD) & $2.06(2.27)$ & $16.3(55.4)$ \\
\hline Update mean in one week, Feb. 2016 (SD) & $5.6(4.5)$ & $5.99(4)$ \\
\hline
\end{tabular}

\subsection{Facebook}

Upon joining Facebook, politicians have two options to create a presence, a personal profile or a page. Pages can be set up by individuals for organizations, brands or public figures. While a personal profile is set up by a politician (or their team), a page may also be set up by another person unrelated to the politician. Most parliamentarians have established a presence on Facebook; only eleven (3.7\%) had not joined. Among the Facebook users, 194 (68.6\%) parliamentarians maintained a personal profile while for twenty $(7 \%)$, only a page existed. A further $69(24.4 \%)$ used both formats. Facebook is not as publically accessible as other social media applications, in particular Twitter. On a personal Facebook profile, the number of friends is cut by default at 5000 . Over two 
thirds of the parliamentarians on Facebook were close to that number (mean number of friends 4361 , SD = 1128). Despite these restrictions, over one third allowed only friends to see the main content of their page, thus reducing access for a wider audience. There are two options to overcome this limitation: opening content for followers, who then receive updates in their newsfeed, or the creation of a Facebook page which allows an unlimited number of followers. ${ }^{8}$ While $46 \%$ of representatives had less than one thousand followers, 14\% reached more than 20,000 (mean 2396, $\mathrm{SD}=3529$ ). Another measure of popularity is the number of 'likes' which extends the reach of posts into other networks. One third of the parliamentarians had attracted less than 500 likes, while slightly more reached up to 1500 likes (37\%). Four representatives had more than 10,000 likes. The median stood at 717 (mean 7923, SD = 41,044). Prominent opposition politician Moon Jae-in (elected President in May 2017) led with 370,000 likes, four times as many as the politician in the second highest position, Ahn Cheol-soo. Ahn, however, did not have a personal profile, but was represented by a page.

Personal Facebook profiles were frequently updated, with three quarters of users doing so within the previous week. In February 2016, the parliamentarians created a total of 2610 posts during one week. About half posted seven times or less, while 15\% updated their status more than twenty times (mean 19 updates, $S D=26.6$ ). The numbers for the week while parliament was in session were lower, with only 1462 posts in total (mean 16, SD = 27.8). Since Twitter accounts can be connected to Facebook, the number of posts on the micro-blogging site may inflate the number of posts on Facebook. Among those with both a personal profile and a page, the former was more likely to be updated frequently, as there were on average 9.8 updates within the February week on a personal profile (mean 9.8, $\mathrm{SD}=10.4$ ), but only 6.6 on average on a page (mean $6.67, \mathrm{SD}=8.1$ ). Regression tests did not reveal clear trends in terms gender, age, or party membership among the users.

More than three quarters of the parliamentary Facebook users did not reply to a post. Only 58 $(22.1 \%)$ engaged with their readers, and fifteen did so more than ten times (5.7\%). Interestingly, the representatives who replied frequently did not post with the same intensity, but focused their activities on personal exchanges. The data collection did not record the number of likes for specific posts and the number of comments by other users on representatives' posts, but the researcher's overall impression was that interaction was limited. These features and their use for communication and debate among visitors warrant further in-depth (qualitative) analysis, as findings from other countries show different trends (e.g. Ross et al., 2015, Sørensen, 2016).

\subsection{Twitter}

Korean parliamentarians were early adapters of Twitter as many opened an account as early as 2009 (see also Lee et al., 2012). Among the parliamentarians in the 19th National Assembly, 242 (85\%) had a Twitter account, and among these, 133 used it with the previous seven days (42.5\% of

8 The analysis of the differences between personal profiles and pages and their effects on democratic engagement merits further research. 
all Twitter users). In total, during one week with parliamentary session, 1888 tweets were posted. The number of posts varied greatly, ranging from 1 to 83 (mean 7.9, SD =11.9, median 4). While parliament was in session, only 1104 tweets went public. While some parliamentarians tweeted only once, one user tweeted 68 times (mean 4.5 tweets, $\mathrm{SD}=8.3$, median 1 ). A number of heavy users contributed to the increase the total: in February 2016, 58 representatives $(23.8 \%)$ posted more than ten times a week, while in the previous November, 40 people $(16.3 \%)$ did post so frequently. No correlation between frequent use of Twitter and age, gender, or party affiliation was found. A preliminary finding of the content analysis suggests that parliamentarians generally used Twitter for self-promotion, such as posting a link to a news report on the politician or a topic close to their interests. The usage data indicates that Twitter is an important tool of communication for some parliamentarians, while for the majority, it is no more than an additional channel to bring information to the public, which they do not use frequently.

Tweets are publically visible and open to public comments, promoting engagement among a broad variety of users. Interactivity can thus be measured by the number of retweets and replies. The number of retweets by representatives in late February 2016 was low; 85\% of parliamentarians did not use this feature at all. Only seven representatives retweeted more than ten posts. 'Super posters' with more than thirty personal tweets were not necessarily also retweeting frequently, but the number of frequent Twitter users among representatives was too small to draw meaningful conclusions. The number of replies to incoming tweets was also very low, as only 21 parliamentarians did so $(8.6 \%)$. Among them, six are replied frequently but they did not retweet to the same amount. The data from the week in the previous November showed similar patterns of limited engagement with commentators. Only four people consistently used all the features of Twitter to engage. Engagement can also be measured by the number of accounts politicians follow. There was some variety, ranging from two to over 190,000, with a median of 6105 accounts being followed (mean 11,869.9, SD $=21.664 .2) .{ }^{9}$ Only ten percent of representatives followed more than 20,000 people.

The number of followers is often treated as an indicator of popularity (e.g. Lee, et al., 2012). In early 2016, then-opposition leader Moon Jae-in had the highest number of followers (with over 900,000 followers). Eleven other representatives had over 100,000 followers while the majority of parliamentarians (nearly 75\%) had less than 15,000. The median number of followers was 7225 (mean 26,639, SD = 86,340.8). Progressive politicians (members of the Minjoo Party, People's Party and Justice Party) attracted a larger number of followers than conservatives. The mean for the Progressives camp was raised by prominent leader, Moon Jae-in (mean 42,877, SD =12,194). Conservatives had a mean of 10,119 followers $(S D=15,007)$. Among the account holders with more than 50,000 followers, two thirds belonged to the progressive camp. In this group, over one third $(37.5 \%)$ were in their first term, but this did not mean they were also younger. Overall, older representatives (over 50) attracted more followers. ${ }^{10}$

\footnotetext{
${ }^{9}$ A study of such networks is beyond the scope of this paper, but see Kim \& Park (2012).

10 The number of popular Twitter accounts (more than 50,000 followers) was too low to produce statistically relevant data, so these are simple descriptions.
} 
These findings are an indication that Twitter is mainly used for self-promotion, rather than as a form of interaction and communication with a broad audience. Combined, the 244 Twitter accounts had around 6.5 million followers in early 2016, although not all accounts following politicians may have been active. Moreover, one person may have followed several politicians. South Korea's population amounts to more than 50 million, so Twitter is a relatively small echo chamber. The number of tweets in one week was lower than 1,900, a drop in the ocean of tweets. Twitter can thus be described as a minor influence on the activities of Korean National Assembly members in early 2016. The effect is more indirect, as influential personalities in the media are likely to use Twitter and read politicians' posts, thus multiplying the spread of messages.

\section{Discussion}

By 2016, Korean National Assembly members had established a presence on a wide variety of social media, but the key observation is the limited number of Korean parliamentarians who are active on social media beyond joining the service and occasional updates. With regard to features, the focus across all media is on the provision of information. Reflecting a different political culture, websites and social media were rarely used for the collection donations, so the following focuses on the interactive features, the provision of information and the promotion of interaction and communication. Politicians in the National Assembly had established a broad presence across forums in the digital world, but did neither rely on the web to engage in primary communication functions nor employ the interactive features of the new ICT in a meaningful way. Websites and blogs do not record the number of visitors, but the audience size, i.e. the number of followers on Twitter, and friends, followers and likes on Facebook, varied substantially. In terms of popularity, well-established representatives dominated the field, supporting the reinforcement perspective. Among the most popular social media users, Ahn Cheol-soo is interesting due to his outsider status. Ahn is famous for starting a successful anti-virus software company (Ahn Lab), and entered politics as an outsider in 2011. Although (or because) he was not affiliated with a party, he was hugely popular, in particular among younger people (Sohn \& Kang, 2012). Yet, despite his background in the IT industry and popularity among the tech-savvy young generation, he was not a frequent user of digital media, but favored more personal contact and the traditional media to promote his message. ${ }^{11}$ After his election to the National Assembly, he continued to travel the country for 'town hall meetings' to seek direct contact with citizens. In recent years, other politicians have followed his example rather than shifting their activities online. Like the tech entrepreneur, they took a more conservative in approach to political communication. This can be read as an indication of the perpetuating effect of political socialization, which supports established patterns of top-down political communication.

In the Korean sample of parliamentarians, the effect of age counters international observations. Among the Korean parliamentarians, the younger representatives were less active than their older

${ }^{11}$ In the week under study, shortly after creating a new political party, Ahn posted 18 tweets and 16 Facebook updates. 
peers (over 50). The higher level of engagement among older parliamentarians could also be a result of a team of assistants (personal communication). The accounts with the highest number of updates belonged to the leaders of the opposition parties, Moon Jae-in and Ahn Cheol-soo. A high volume of posts by a politician raises questions about their personal involvement in these accounts. In practical terms, such numbers can only be managed with the help of assistants, rather than constant personal attention by the politician themselves, but only interviews could shed light on this. The use of intermediaries undermines the direct access argument of proponents of direct democracy. Other variables, such as gender, hometown, and experience in the National Assembly did not offer any further insights into distinguishing features of social media.

Tables 3 and 4 look at the primary communication functions used. The shift from blogs to social media is visible in the direct comparison. The mean number of posts on Facebook is more than three times that of websites and blogs and more than double compared to tweets (Table 3). The large variation in the number of posts shows the different levels of enthusiasm in the provision of information and communication with followers.

Table 3: number of posts on websites, blogs, Facebook and Twitter, in one week, February 2016 (source: author)

\begin{tabular}{|l|l|l|l|l|}
\hline & Website & blog & Facebook & Twitter \\
\hline Mean & $\mathbf{5 . 6}$ & $\mathbf{6}$ & $\mathbf{1 9}$ & $\mathbf{7 . 9}$ \\
\hline SD & 4.5 & 4 & 26.6 & 11.9 \\
\hline
\end{tabular}

The number of representatives who engaged frequently on social media was limited. Communication remained a one-way street; on social media, comments, replies and retweets by parliamentarians were rare (Table 4). Only $22 \%$ replied to comments on Facebook posts during the February week, while $8.6 \%$ replied on Twitter. Just under $15 \%$ retweeted a post by someone else. The opportunity to inform and consult citizens about parliamentary business and decisions was rarely employed. Representatives reduced their posts during session time rather than actively seeking input by citizens.

Table 4: Engagement with commentators on Facebook and Twitter, in one week, February 2016 (source: author)

\begin{tabular}{|l|l|l|l|l|}
\hline & $\begin{array}{l}\text { Number of par- } \\
\text { liamentarians } \\
\text { engaging }\end{array}$ & $\begin{array}{l}\text { In \% of ser- } \\
\text { vice users }\end{array}$ & $\begin{array}{l}\text { Engaged more } \\
\text { than } 10 \text { times }\end{array}$ & $\begin{array}{l}\text { In \% of ser- } \\
\text { vice users }\end{array}$ \\
\hline Facebook replies & 58 & $22.1 \%$ & 15 & $5.7 \%$ \\
\hline Retweet & 36 & $14.8 \%$ & 7 & $2.9 \%$ \\
\hline Twitter replies & 21 & $8.6 \%$ & 6 & $2.4 \%$ \\
\hline
\end{tabular}




\section{Conclusion}

This paper set out to place the online political communication of South Korean parliamentarians in the literature on the development of new means of political communication in the internet era. Early observers held high expectations of new media as an invigorative force of democracy but this may been rooted in technological determinism. Empirical evidence supports the reinforcement theory that social media alone will not revolutionize political activities. The optimistic assumption that new ICT promote direct engagement and remove barriers between politicians and citizens is countered by this case study. The study reveals that the majority of Korean National Assembly members were not utilizing ICT and social media as a means of communication frequently. Although they established a presence in the popular social media of the day, it was mainly used as a one-way channel to distribute information, following a top-down pattern. Parliamentarians continued to maintain established patterns of political communication by providing information but not engaging in dialogue. The results suggest that the key players - politicians - are not necessarily interested in opening new avenues of political communication, even though they possess the technological means and know how. In terms of direct interaction while parliament is in session, the results were also disappointing. Consultation between voters and representatives during parliamentary sessions - or outside - did not occur on Twitter or other social media. While no longer analog, South Korean National Assembly members had not become fully digital either and certainly were not undertaking efforts to increase citizen involvement through new media. Such attitudes limit the potential for changes from the bottom-up. Citizens who note the lack of engagement by politicians expand their general distrust to politicians' online presence and are unlikely to seek such avenues of participation (personal communication). This counters the optimistic assumptions about a trickle-up effect of social media use.

The Korean case adds to the body of literature on digital political communication, contributing data from a relatively new democracy with a high level of online activities. It shows that high levels of internet access and usage as well as acceptance of social media in a country do not automatically lead to an increase in the means and levels of citizens' engagement and political participation in representative democracy. Proponents of digital deliberation and digital democracy may well overestimate the openness of politicians - and citizens - toward new practices and behaviors. This does not, however, mean that digital media should be ruled out as political tools. The dichotomy of representative democracy versus direct democracy may be hindering the debate, as there are communicative elements to representative democracy that digital media may encourage to explore further (Coleman, 2005). ICT and social media open additional means of engagement that, with some commitment by users on both sides of the political divide, could develop into a more interactive tool. This may include innovative forms of participation outside the established patterns. Rather than bringing a revolution to Korean politics, digital media are bringing slow changes to challenge 'politics as usual'.

The paper also highlights methodological challenges. Each new media development opens new opportunities for participation and communication, but also brings challenges to the researcher, not the least in terms of methodology. New fields of research opened with the rise (and fall) of websites, blogs and social media like Facebook and Twitter. The potential for deliberation in these 
platforms continues to be of practical as well as academic interest. Popular commentary tends to focus on numbers disregarding further impact (but see Cha et al., 2010). Measuring impact is not only a question of numbers but also of depth, which can only be explored in a subsequent qualitative analysis of posts. Despite all the reports about the influence of Twitter on Korean politics, for instance, outside election time, parliamentarians posted fewer than 1,900 tweets in one week, hardly an endorsement of the political potential of the service. With regard to social media analysis, one starting point would be an expansion of existing frameworks used to analyze blogs, building on frames from studies in political communication. The differences between platforms and the effect of different formats (e.g. Facebook pages versus personal profiles) merit further work, as well as a closer look at who actually posts, a politician or an assistant. Analyses of the connection between new media and political participation on politicians' accounts would include contents of comment sections, since pages and posts by politicians may serve as an entry point for discussion, even across different platforms. In some countries, but not Korea, citizens have already co-opted politicians' sites as a forum of discussion. The connection between online engagement and real world outcomes continues to pose a problem in terms of data collection, so further research and exploration of research methods are necessary.

\section{References}

Bakker, T.P., \& de Vreese, C.H. (2011). Good news for the future? Young people, internet use, and political participation. Communication Research, 38(4), 451-470.

Bennett, W.L. (2003). Communicating global activism: Strengths and vulnerabilities of networked politics. Information, Communication \& Society, 6(2):143-168.

Bennett, W.L. (2008). Changing Citizenship in the Digital Age. In W.L. Bennett (Ed.), Civic Life Online: Learning How Digital Media Can Engage Youth (pp. 1-24). The John D. and Catherine T. MacArthur Foundation Series on Digital Media and Learning. Cambridge, MA: The MIT Press.

Blühdorn, I. (2013). Simulative Demokratie. Neue Politik nach der postdemokratischen Wende. Frankfurt/M.: Suhrkamp.

Blumler, J.G., \& Coleman, S. (2001). Realising Democracy Online: A Civic Commons in Cyberspace. London: CitizensOnline.

Blumler, J.G., \& Kavanagh, D. (1999). The third age of political communication: influences and features. Political Communication, 16(3), 209-230.

Brandenburg, H. (2006). Pathologies of the Virtual Public Sphere. In S. Oates, D. Owen \& R. K. Gibson (Eds.), The Internet and Politics: Citizens, Voters and Activists (pp. 207-222). London: Routledge.

Cha, M., \& Haddadi. H., \& Benevenuto, F. \& Gummadi, K. P. (2010). Measuring User Influence in Twitter: The Million Follower Fallacy, In AAAI (ed.) Proceedings of 4th International AAAI Conference on Weblogs and Social Media (pp.10-17). Retrieved June 20, 2016, from https://www.aaai.org/ocs/index.php/ICWSM/ICWSM10/paper/download/1538/1826. 
Chadwick, A. (2011). Web 2.0: New Challenges for the Studies of E-Democracy in an Era of Informational Exuberance. In S. Coleman \& P.M Shane (Eds.), Connecting Democracy: Online Consultation and the Flow of Political Communication (pp. 45-74). Cambridge, MA: MIT Press.

Chadwick, A. \& Howard, P.N., eds. (2009). The Routledge Handbook of Internet Politics. Abdingdon: Routledge.

Chang, W.-Y. (2005). The Internet, alternative public sphere and political dynamism: Korea's non-gaek* (polemist) websites. The Pacific Review, 18(3), 393-416.

Chang, W.Y., \& Lee, W.-T. (2006). Cyberactivism and political empowerment in civil society: A comparative analysis of Korean cases. Korea Journal, 46(4), 136-167.

Chang, D. (2014). Leveling the playing field: Social media and politics in South Korea. Global Asia, 9(2), 30-35.

Chebib, N.K., \& Sohail, R.M. (2011). The reasons social media contributed to the 2011 Egyptian Revolution. International Journal of Business Research and Management, 2(3), 139-162.

Choi, J.I., \& Chang, J. H. (2015). A study on finding influential Twitter users by clustering and ranking techniques. Journal of the Korea Industrial Information Systems Research, 20(1), 19-26.

Christensen, H.S. (2012). Simply slacktivism? Internet participation in Finland. Journal of E-Democracy and Open Government, 4(1), 1-23.

Coleman, S. (1999). Cutting out the Middle Man: How Deliberative is Online Political Discussion. In B. N. Hague \& B. D. Loader (Eds.), Digital Democracy: Discourse and Decision Making in the Information Age (pp. 195-210). London: Routledge.

Coleman, S. (2005). New mediation and direct representation: Reconceptualizing representation in the digital age. New Media \& Society, 7(2), 177-198.

Coleman, S., \& Blumler, J. G. (2009). The Internet and Democratic Citizenship: Theory, Practice and Policy. Cambridge: Cambridge University Press.

Coleman, S., \& Shane, P.M., eds. (2011). Connecting Democracy: Online Consultation and the Flow of Political Communication. Cambridge, MA: MIT Press.

Crouch, C. (2004). Post-Democracy. Cambridge: Polity Press.

Dahlberg, L. (2007). Rethinking the fragmentation of the cyberpublic: From consensus to contestation. New Media \& Society 9(5): 827-848.

Dalton, R.J. \& Wattenberg, M.P., eds. (2000). Parties without Partisans: Political Change in Advanced Industrialised Democracies. Oxford: Oxford University Press.

Davis, R. (2009). Typing Politics: The Role of Blogs in American Politics. Oxford: Oxford University Press.

Emarketer. (2014) Twitter use down as Facebook holds steady in South Korea. January 31, 2014. Retrieved June 15, 2016, from http:/ / www.emarketer.com/Article/Twitter-Use-Down-Facebook-Holds-SteadySouth-Korea/1010573.

Enli, G.S., \& Skogerbø, E. (2013). Personalized campaigns in party-centred politics. Information, Communication \& Society 16(5): 757-774. 
Farrell, H., \& Drezner, D. (2008). The power and politics of blogs. Public Choice, 134(1), 15-30.

Frame, A., \& Brachotte, G. (2015). Le tweet stratégique: Use of Twitter as a PR tool by French politicians. Public Relations Review, 41(2), 278-287.

Gibson, R.K. (2015). Party change, social media and the rise of 'citizen-initiated' campaigning. Party Politics, 21(2), 183-197.

Gibson, R.K., \& Cantijoch, M. (2013). Conceptualizing and measuring participation in the age of the internet: Is online political engagement really different to offline? Journal of Politics, 75(3), 701-716.

Gibson, R.K., \& Lusoli, W., \& Ward, S. (2008). Nationalizing and normalizing the local? A comparative analysis of online candidate campaigning in Australia and Britain. Journal of Information Technology \& Politics, 4(4), 15-30.

Gibson, R.K., \& McAllister. I. (2006). Does cyber-campaigning win votes? Online communication in the Australian election. Journal of Elections, Public Opinion \& Parties, 16(3), 243-263.

Habermas, J. (1990/1962). Strukturwandel der Öffentlichkeit. Untersuchungen zu einer Kategorie der bürgerlichen Gesellschaft. Frankfurt/M.: Suhrkamp.

Halupka, M. (2014). Clicktivism: A systematic heuristic. Policy \& Internet, 6(2): 115-132.

Hansen, K.M., \& Kosiara-Pedersen, K. (2014). Cyber-campaigning in Denmark: Application and effects of candidate campaigning. Journal of Information Technology \& Politics, 11(2), 206-219.

Hellmann, O. (2014). Party system institutionalization without parties: Evidence from Korea. Journal of East Asian Studies, 14(1), 53-84.

Hermanns, H. (2015). Die Entfaltung der E-Demokratie. In E.J. Lee, H.B. Mosler (Eds.), Länderbericht Korea (pp. 145-158). Bonn: Bundeszentrale für politische Bildung.

Hong, S., \& Nadler, D. (2011). Does the Early Bird Move the Polls? The use of the social media tool 'Twitter' by U.S. politicians and its impact on public opinion. In: Proceedings of the International Conference on Digital Government Research (pp. 182-186). Retrieved on June 15, 2016 from http://dl.acm.org/citation.cfm?id=2037583.

Hsu, C.-1., \& Park, H.W. (2011). Sociology of hyperlink networks of Web 1.0, Web 2.0, and Twitter: A case study of South Korea. Social Science Computer Review, 29, 354-368.

Hsu, C.L., \& Park, S.J., \& Park, H.W. (2013). Political discourse among key Twitter users: The case of Sejong city in South Korea. Journal of Contemporary Eastern Asia, 12(1), 65-79.

Internet Statistics (2016). Internet usage in Asia. Retrieved June 20, 2016 from http://www.internetworldstats.com/stats3.htm.

Jensen, M.J., \& Bang, H.P. (2013). Occupy Wall Street: A new political form of movement and community? Journal of Information Technology \& Politics, 10(4), 444-461.

Kies, R. (2010). Promises and Limits of Web-deliberation. New York: Palgrave Macmillan. 
Kim, J. (2014). The Party System in Korea and Identity Politics. In L. J. Diamond \& G.-W. Shin (Eds.), New Challenges for Maturing Democracies in Korea and Taiwan (pp. 71-105). Palo Alto: Stanford University Press.

Kim, M., \& Park, H.W. (2012). Measuring Twitter-based political participation and deliberation in the South Korean context by using social network and Triple Helix indicators. Scientometrics, 90(1): 121-141.

Kim, Y. (2011). The contribution of social network sites to exposure to political difference: The relationships among SNSs, online political messaging, and exposure to cross-cutting perspectives. Computers in Human Behavior, 27(2), 971-977.

Kim, Y.C., \& Kim, J.W. (2009). South Korean democracy in the digital age: The Candlelight Protests and the internet. Korea Observer, 40(1), 53-84.

Kluver, R., \& Jankowski, N.W., \& Foot, K.A., \& Schneider, S.M., eds. (2007). The Internet and National Elections: A Comparative Study of Web Campaigning. London: Routledge.

Koc-Michalska, K., \& Lilleker, D. G., \& Vedel, T. (2016). Civic political engagement and social change in the new digital age. New Media \& Society, 18(3), 1807-1816.

Lankov, A. (2011). How Korea has become world's most wired country. The Korea Times, 30 January. Retrieved November 12, 2017 from

http://www.koreatimes.co.kr/www/news/special/2012/05/113_80600.html.

Larsson, A.O., \& Moe, H. (2011). Studying political microblogging: Twitter users in the 2010 Swedish election campaign. New Media \& Society 14(5), 729-747.

Lee, M.H. (2016). Kakao story users ditching the app in droves. Korean Bizwire, 11 April. Retrieved June 15, 2016, from http:/ / koreabizwire.com/kakao-story-users-ditching-the-app-in-droves/52959.

Lee, W.T., \& Chang, W.Y., \& Min, H. (2012). Social Networking Strategies of Political Parties and Politicians in South Korea: Current State and Its Implications. Korean Political Science Review, 46(6):109-140.

Lilleker, D.G., \& Pack, M. \& Jackson, N. (2010). Political parties and web 2.0: the Liberal Democrat Perspective. Politics, 30(2), 105-112.

Lim, Y.S., \& Park, H.W. (2013). The structural relationship between politicians' web visibility and political finance networks. New Media \& Society, 15(1), 93-108.

Macnamara, J., \& Kenning, G. (2014). E-Electioneering 2007-13: Trends in online political campaigns over three elections. Media International Australia, 152(1): 57-74.

Madianou, M. (2012). Humanitarian campaigns in social media: Network architectures and polymedia events. Journalism Studies, 14(2): 249-266.

Margolis, M., \& Resnick, D. (2000). Politics as Usual: The Cyberspace 'Revolution'. London: Sage.

Min, K. B. (2008). Analog government, digital citizens. Global Asia, 3(3), 94 -103.

Ministry of Science, ICT and Future Planning (MSIFP). 2015 Survey of the Internet Usage. Retrieved March 9, 2016, from http://isis.kisa.or.kr.

Morris, D. (1999). vote.com. Los Angeles, CA: Renaissance Books. 
Morozov, E. (2009). Brave new world of slacktivism. Foreign Policy, 19 May. Retrieved July 16, 2017 from http://www.npr.org/templates/story/story.php?storyId=104302141.

Nielsen, R.K. (2011). Mundane internet tools mobilizing practices, and the coproduction of citizenship in political campaigns. New Media \& Society 13(5): 755-771.

Norris, P. (2000). A Virtuous Circle: Political Communications in Post Industrial Societies. Cambridge: Cambridge University Press.

Norris, P. (2001). Digital Divide: Civic Engagement, Information Poverty, and the Internet Worldwide. Cambridge: Cambridge University Press.

Norris, P. (2011). Democratic Deficit: Critical Citizens Revisited. Cambridge, Cambridge University Press.

Park, C.S. (2013). Does Twitter motivate involvement in politics? Tweeting, opinion leadership, and political engagement. Computers in Human Behavior, 29(4), 1641-1648.

Park, H.W., \& Kim, C.-S., \& Barrett, G.A. (2004). Socio-communicational structure among political actors on the web in South Korea: The dynamics of digital presence in cyberspace. New Media \& Society, 6(3), 403-423.

Park, H.W., \& Kluver, R. (2007). E-Relationships in Politicians' Blogs in South Korea: Comparing Online and Offline Social Networks. Paper presented at the Annual Conference of the International Communication Association, San Francisco, May 24-28, 2007.

Park, S. J., \& Lim, Y. S., \& Sams, S., \& Nam, S. M., \& Park, H. W. (2011). Networked politics on Cyworld: The text and sentiment of Korean political profiles. Social Science Computer Review, 29, 288-299.

Park, S. (2014). A study on the change of presidential candidate selection method in Korea. Korean Political Science Review, 48(4), 197-224.

Pickerill, J. 2006. Radical politics on the net. Parliamentary Affairs, 59(2), 266-282.

Putnam, R.D. (2000). Bowling Alone: The Collapse and Revival of American Community. London: Simon and Schuster.

Rheingold, H. (1994). The Virtual Community - Homesteading on the Electronic Frontier. New York, N.Y.: HarperPerennial.

Riles, J. M., \& Pilny A., \& Tewksbury, D. (2017). Media fragmentation in the context of bounded social networks: How far can it go? New Media \& Society. DOI: https:// doi.org/10.1177/1461444817696242.

Ross, K., \& Fountaine, S., \& Comrie, M. (2015). Facing up to Facebook: politicians, publics and the social media(ted) turn in New Zealand. Media, Culture \& Society, 37(2), 251-269.

Shane, P.M. (2004). Democracy Online: The Prospects for Political Renewal through the Internet. New York: Routledge.

Skoric, M.M., \& Zhu, Q., \& Goh, D., \& Pang, N. (2016). Social media and citizen engagement: A meta-analytic review. New Media \& Society, 18(9), 1817-1839.

Socialbackers. (2016). Twitter Statistics for South Korea. Retrieved June 20, 2016 from http://www.socialbakers.com/statistics/Twitter/profiles/south-korea/. 
Socialbackers. (2017). Twitter Statistics for South Korea. Retrieved August 20, 2017 from http://www.socialbakers.com/statistics/Twitter/profiles/south-korea/.

Sohn, Y., \& Kang, W.-T. (2013). South Korea in 2012: An election year under rebalancing challenges. Asian Survey, 53(1), 198-205.

Sørensen, M.P. (2016). Political conversations on Facebook - the participation of politicians and citizens. Media, Culture \& Society, 38(5), 664-685.

Strandberg, K. (2013). A social media revolution or just a case of history repeating itself? The use of social media in the 2011 Finnish parliamentary elections. New Media \& Society, 15(8), 1329-1347.

Stein, L. (2009). Social movement web use in theory and practice: a content analysis of US movement websites. New Media \& Society, 11(5), 749-771.

Trippi, J. (2004). The Revolution will not be Televised. New York: ReganBooks.

Valenzuela, S., \& Kim, Y., \& Gil de Zuniga, H. (2012). Social networks that matter: Exploring the role of political discussion for online political participation. International Journal of Public Opinion Research, 24(2), 163184.

Van Alstyne, M., \& Bryndfisson, E. (1997). Electronic Communities: Global Village or Cyberbalkans? Cambridge: MA: MIT Sloan School.

Vergeer, M., \& Hermans, L., \& Sams, S. (2011). Online social networks and micro-blogging in political campaigning: The exploration of a new campaign tool and a new campaign style. Party Politics, 19(3), 477-501.

Ward, S., \& Gibson, R.K., \& Lusoli, W. (2003). Online participation and mobilisation in Britain: Hype, hope and reality. Parliamentary Affairs, 56(4), 652-668.

Williamson, A. (2013). Social Media Guidelines for Parliaments. Geneva: Interparliamentary Union.

Wright, S. (2012). Politics as usual? Revolution, normalization and a new agenda for online deliberation. New Media \& Society, 14(2), 244-261.

Yoon, S.-W. (2017). Social Media Fatigue Spreading. The Korea Times, 22 June. Retrieved July 17, 2017 from http://www.koreatimes.co.kr/www/tech/2017/06/133_231779.html.

Yun, S. (2003). The internet and the 2002 presidential election in South Korea. Korea Journal, 43(2), 209-229.

\section{About the Author}

Heike Hermanns

Dr. Heike Hermanns joined the Department of Political Science at Gyeongsang National University, J inju, South Korea in 2009 and was promoted to Associate Professor in 2013. Previously, she has studied and worked in Australia, Germany, South Korea and the UK. Her main research interests are democracy and democratization, the challenges of new media for democracy, environmental politics, and Korean politics. 